\title{
EFFECT OF OSMOTIC DEHYDRATION ON MECHANICAL AND RHEOLOGICAL PROPERTIES OF PUMPKIN DRIED WITH MICROWAVE METHOD IN REDUCED PRESSURE CONDITIONS
}

\author{
Bogdan Stępień, Radosław Maślankowski, Marta Pasławska, Klaudiusz Jałoszyński, \\ Mariusz Surma
}

Institute of Agricultural Engineering, Wroclaw University of Environmental and Life Sciences

${ }^{*}$ Corresponding author: e-mail: bogdan.stepien@up.wroc.pl

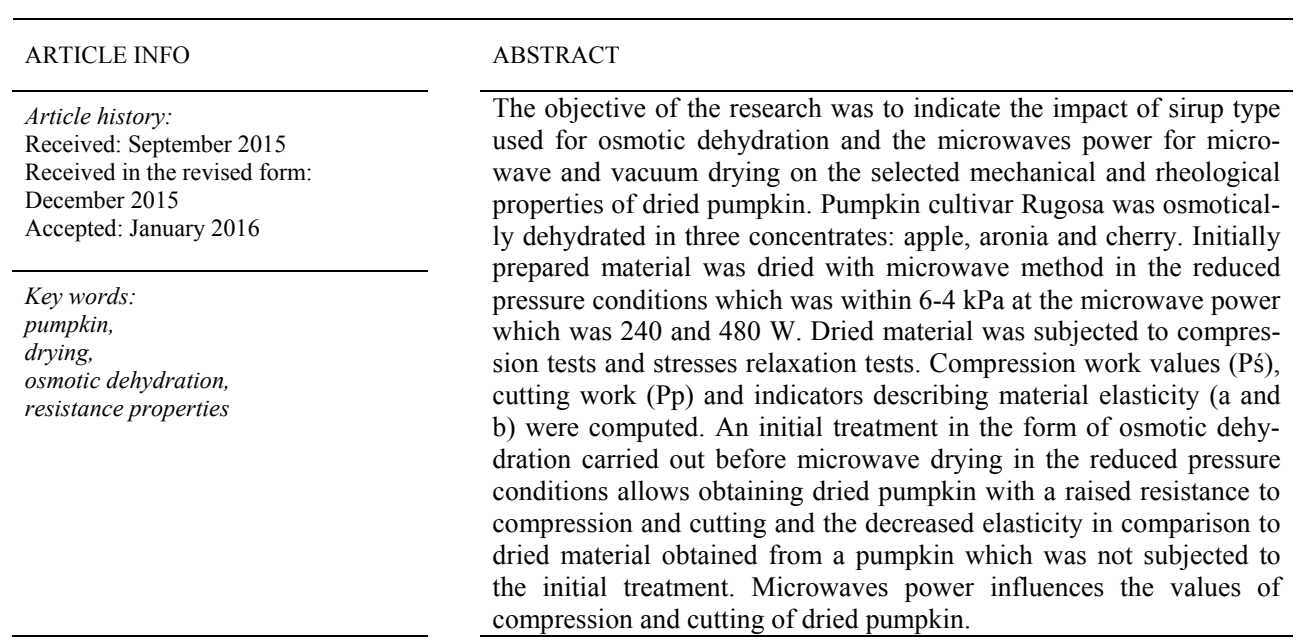

\section{Introduction}

The increase of pumpkin popularity (Cucurbita) as a product designated for consumption results from at least two reasons. Firstly, we deal with positive feeding changes of a considerable part of society. Secondly, it results from a considerable simplicity of cultivation, high nutritive value of pumpkin and high activity of researchers in treating new cultivars (Pękosławska-Garstka and Lenart, 2010). For feeding purposes the most often three cultivars are cultivated: Winter squash (Cucurbita maxima Duch.), cucurbita pep (Cucurbita pepo L.) and cucurbita moschata (Cucurbita moschata Duch.) (Nawirska et al., 2009). Fresh mass of fruit includes 2 to $10 \mathrm{mg} \cdot(100 \mathrm{~g})^{-1}$ of carotene. Carotenoids are the source of vitamin $\mathrm{A}$ and in particular of $\beta$-carotene. It is necessary for correct development of a man and prevents free radicals (Garcia et al., 2007). Pumpkin also is a rich source of pectins, vitamins (B1, B2, PP and C) and mineral elements (magnesium, calcium, phosphorus, potassium (Nawirska et al., 2009). It is a vegetable which is hard to store on account of fast 
and numerous changes in texture and chemical composition. Chemical changes take place, which influence nutritive value as well as sensory evaluation (Sojak and Głowacki, 2010; Stępień et al., 2013).

All agricultural raw materials have a basic disadvantage related to seasonality of obtaining raw material. Therefore, there is a need to search for processing methods and new techniques of preserving this type of materials. It seems that osmotic dehydration may be an advantageous technological treatment which leads to obtaining products expected by consumers (Garcia et al., 2007), and it may be treated as an initial processing before e.g. drying, which significantly changes the quality of dried material (Ciużyńska and Lenart, 2009; Janowicz et al., 2008; Stępień et al., 2013). Osmotic dehydration is often used as an independent technological treatment which allows obtaining products of high quality at the simultaneous reduced humidity in comparison to the initial material. It is a treatment which is the most often used as an initial processing before drying or freezing. In such a situation, osmotic dehydration is a technological process element which prepares raw material for further processing. Substances used for osmotic dehydration must meet several requirements. They must be able to form relevantly high osmotic pressure, they should have a nice smell and good taste and they cannot be toxic. The course of osmotic dehydration process depends on the type of the osmoactive substance, concentration of solution, process duration and the type and condition of the cell structure of material subjected to dehydration. Many researchers have made attempts to describe the kinetics of the mass transport during dehydration (Garcia et al., 2007; Ghosh et al., 2004; Kowalska and Lenart, 2001). Similar number of papers is related to physical and chemical properties of osmotic dehydration products or products of drying with osmotic dehydration as an initial processing (Pękosławska-Garstka and Lenart, 2010; Janowicz et al., 2008; Sitkiewicz and Lenart, 2002).

The use of microwaves for supplying heat to dried material significantly speeds water removal because heat is supplied to the entire volume of material and not only to its surface (Alibas, 2007). Combination of microwave drying with under pressure is a solution considered by many researchers as very promising because the process is carried out in milder temperature conditions which less destructively affect the quality of dried material (Stępień, 2009; Mui et al.., 2002; Sham et al., 2001). Dried materials obtained with the microwave method in the reduced pressure conditions are characterized by more advantageous reconstitution properties and better retention of vitamin $\mathrm{C}$, lower density and softer texture in comparison to traditional convective drying (Khraisheh et al., 2004; Jałoszyński et al., 2010). Changes concerning the texture are very essential because as previous research showed, they directly affect the results of sensory assessment of products designated for consumption thus on the consumers' acceptance of products (Stępień et al., 2013).

\section{Objective, scope and methodology of research}

The objective of the research was to determine the impact of osmotic dehydration of pumpkin carried out in various sirups on the selected mechanical properties (values of the compression and cutting work) and rheological (values of indexes $a$ and $b$ which describe the elasticity of material) for dried material obtained with the microwave method in the reduced pressure conditions. 
Effect of osmotic dehydration...

Samples were cut from pumpkin pulp of Moschate cultivar, Rugosa cultivar in the form of a cube with the length of $10 \mathrm{~mm}$. The fourth part of prepared samples was subjected to drying without initial processing to treat the research results as a control sample. The remaining material was divided into three equal parts and prepared for osmotic dehydration in the following concentrates (with a concentration of non-volatile compounds with water steam which is $\left(66.0^{\circ} \mathrm{Bx}\right)$, chokeberry $\left(67.9^{\circ} \mathrm{Bx}\right)$ and cherry $\left(68.4^{\circ} \mathrm{Bx}\right)$. Concentration of the concentrate together with osmotic dehydration duration and the ratio of solution to the raw material mass have a decisive impact on the intensity of the process course. Due to relatively high concentration of solutions, transport of mass was intensive thus the process duration was limited to 4 hours. The ratio of osmotic solution mass to the raw material mass was 4:1 according to other researchers (Lewicki et al., 2002; Pereira et al., 2007). Temperature of osmotic solution was $20 \pm 2^{\circ} \mathrm{C}$. After treatment material was placed on sieves and then dried on tissue paper.

Drying with the microwave technique in the reduced pressure conditions (MPV) was carried out with the use of SM 200 laboratory installation, construction of which, schematic representation and the principle of operation were presented in other publications (Stępień, 2009). $60 \mathrm{~g}$ of a sample was placed in a glass container. Two powers of microwaves were used 240 and $480 \mathrm{~W}$. Negative pressure in the drying chamber was reduced in comparison to atmospheric pressure and fluctuated during the process within 6 to $4 \mathrm{kPa}$. In order to obtain a relevant amount of uniform dried material, each time 5 iterations of drying were carried out and the obtained product was vacuum packed to attested bags.

Tests on mechanical and rheological properties of obtained dried material were carried out on Instron 5566 testing machine equipped with a head of 0.5 class with the maximum loading of $100 \mathrm{~N}$. The compression process was performed with the use of a round board of $20 \mathrm{~mm}$ diameter. A single sample was compressed with the speed of deformation of 1.8 $\mathrm{mm} \cdot \mathrm{min}^{-1}$ which means that the test was carried out in quasistatic conditions. The test was stopped after a sample was deformed by $20 \%$ of its initial height. 5 iterations of measurements were carried out. A modified Instron attachment with the angle of a knife-blade and a cutter tip angle of $60^{\circ}$ was applied for cutting dried material. Single samples were cut with the $10 \mathrm{~mm} \cdot \mathrm{min}^{-1}$ moving speed of a head with a blade. On account of greater differences of cutting forces values which occur in particular tests, 10 iterations of measurements of dried pumpkin cutting work were carried out. Stresses relaxation tests were carried out with the use of devices used in the compression tests. The first phase of the process, consisting in formation in the investigated material of a stress which corresponds to the average stress in the deformed sample by $20 \%$ of its initial height, was carried out at the head with a board move speed of $10 \mathrm{~mm} \cdot \mathrm{min}^{-1}$. Registration of stresses changes during the relaxation process was carried out every 15 minutes. For analysis of the stresses relaxation course the procedure suggested by Stropka and Gołacki and used many times was applied (2006) (Stępień, 2009; Stępień et al., 2013). The procedure allows calculation of the indexes values $a$ and $b$, which have a precise physical interpretation. The value of index $a$ defines the level, to which stresses during relaxation test disappear and the constant $b$ informs on the speed of disappearance of stresses.

With the use of a computer programme Statistica 10.5 a two factor analysis of variance was carried out at the confidence level of $\alpha=0.05$ in order to determine the significance of the osmotic dehydration impact and the power of microwaves on the analysed properties. 
B. Stępień, R. Maślankowski, M. Pasławska, K. Jałoszyński, M. Surma

Fisher's NIR post-hoc test was used for the analysis of the impact of the osmotic solution type and the power of microwaves on mechanical and rheological properties.

\section{Analysis of results}

Decrease of the concentrate concentration is one of the indexes which show the intensity of the osmotic dehydration process course. Apple concentrate concentration after 4 hours of dehydration dropped from 66.0 to $60.5^{\circ} \mathrm{Bx}$. For the remaining concentrates the reduction of concentration was respectively: chokeberry sirup from 67.9 to $60.7^{\circ} \mathrm{Bx}$ and cherry sirup from 68.4 to $60.3^{\circ} \mathrm{Bx}$. It means that a considerable amount of moisture from raw material got to the solution causing reduction of pumpkin moisture after initial treatment. It is reflected in pumpkin moisture directly after the initial treatment. Raw material moisture was $83.1 \%$ and decreased after osmotic dehydration to the level from $59.9 \%$ to $67.8 \%$ in relation to concentrate (table 1). Moisture of dried material was from 3.8\% for the product obtained from a pumpkin which was osmotically dehydrated in apple sirup and dried with the use of microwaves which was $480 \mathrm{~W}$ to $5.1 \%$ for dried material obtained from a pumpkin dehydrated in chokeberry sirup and dried with the use of microwaves which was 240 W. Based on the previous experimental research it was assumed that minimum differences in the moisture of dried material did not influence significantly the investigated mechanical and rheological properties (Stępień, 2009).

Table 1.

Pumpkin moisture directly after osmotic dehydration and moisture of dried material obtained with microwave method in the conditions of reduced pressure

\begin{tabular}{lcccccc}
\hline \multicolumn{2}{c}{$\begin{array}{c}\text { Moisture after osmotic dehydration } \\
(\%)\end{array}$} & \multicolumn{4}{c}{$\begin{array}{c}\text { Moisture after MPV drying } \\
(\%)\end{array}$} \\
\hline $\begin{array}{l}\text { Apple } \\
\text { sirup }\end{array}$ & $\begin{array}{c}\text { Chokeberyy } \\
\text { sirup }\end{array}$ & $\begin{array}{c}\text { Cherry } \\
\text { sirup }\end{array}$ & $\begin{array}{c}\text { Power } \\
\text { Of micro- } \\
\text { waves }\end{array}$ & $\begin{array}{c}\text { Apple } \\
\text { sirup }\end{array}$ & $\begin{array}{c}\text { Chokeberry } \\
\text { sirup }\end{array}$ & $\begin{array}{c}\text { Cherry } \\
\text { sirup }\end{array}$ \\
\hline \multirow{2}{*}{59.9} & 63.0 & 67.8 & $\begin{array}{c}240 \mathrm{~W} \\
480 \mathrm{~W}\end{array}$ & 4.2 & 5.1 & 4.7 \\
& & & 3.8 & 4.8 & 4.3 \\
\hline
\end{tabular}

A cell structure of fresh pumpkin allowed free penetration of osmoactive substance to the inside of the material. High concentration of osmotic solution and viscosity of liquid related thereto caused formation of a thick ca. $1 \mathrm{~mm}$ thick structure on the edges of samples, which strongly impeded the exchange of mass during drying and significantly changed the investigated physical properties of material (photo 1). The results of supplying heat to the sample with the use of microwaves are presented in the photo. Inside a high pressure was formed resulting from impeding the transport of moisture outside through a layer of osmoactive substance. 


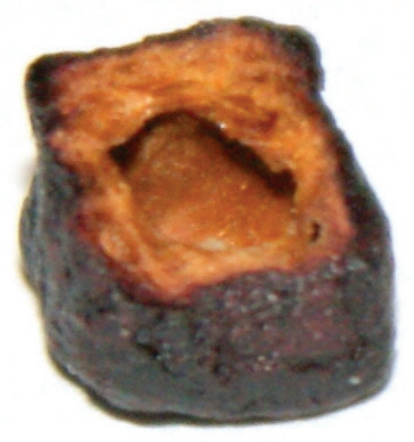

Photo 1. Exemplary photo of a cut sample of pumpkin dehydrated in cherry sirup

Osmotic dehydration of pumpkin allowed obtaining dried material with a very high brittleness. It is proved by exemplary courses of compression of dried material obtained with the use of microwaves which were 240 and $480 \mathrm{~W}$ (figure 1). Both during compression tests and cutting tests pumpkin dried with microwaves in the conditions of the reduced pressure with the use of a $480 \mathrm{~W}$ microwaves sudden changes of forces occurred which proved micro-cracks of a structure during tests. Increase of microwaves from $240 \mathrm{~W}$ to 480 W had an explicit effect on this phenomenon. It was significant for determination of dried material resistance to compression, cutting and elasticity. Frequent and sudden decrease of force values occurring during compression or cutting dried material prove that pumpkin dehydrated by means of osmosis before microwave - under pressure drying is hard and brittle. Thus, resistance of dried material to compression was defined as the compression work value $\left(P s^{\prime}\right)$, because it includes then both forces during a test as well as deformation.

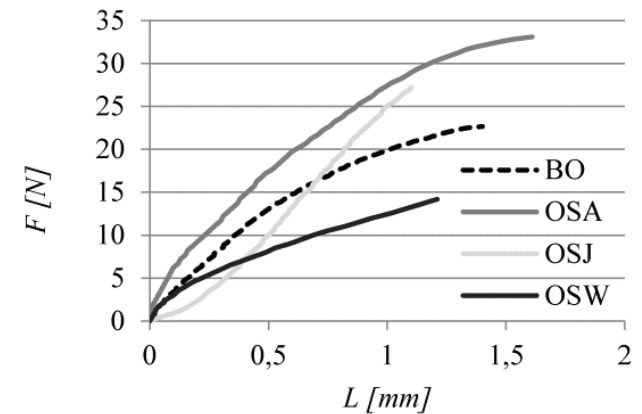

$240 \mathrm{~W}$

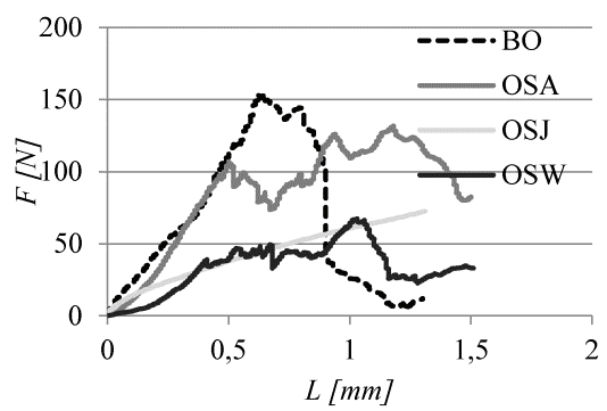

$480 \mathrm{~W}$

Figure 1. Exemplary plots of the compression process of dried pumpkin (BO - without initial processing, OSA - dehydrated in chokeberry sirup, OSJ - dehydrated in apple sirup, OSW - dehydrated in cherry sirup)

Analysis of cutting of dried pumpkin was similar. Both compression work values as well as cutting work $(P p)$ values were calculated with a trapezoid method which includes 
the surface area under compression or cutting curves. Figure 2 presents the values of compression of pumpkin dried with microwaves in conditions of the reduced pressure in comparison to the inputs of work required to deform dried pumpkin which was not subjected to initial treatment.

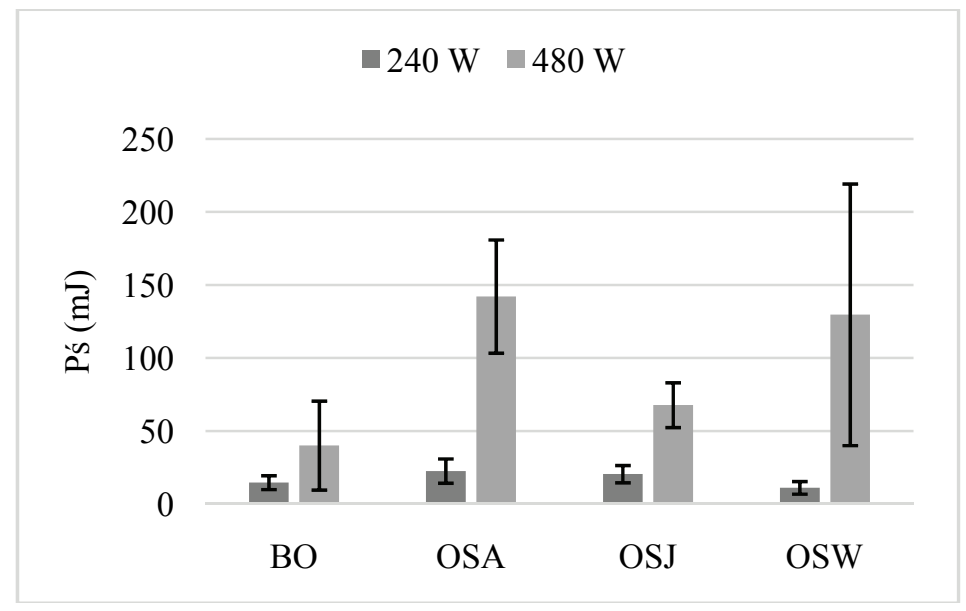

Figure 2. Values of the compression process of dried pumpkin (BO - without initial processing, OSA - dehydrated in chokeberry sirup, OSJ - dehydrated in apple sirup, OSW - dehydrated in cherry sirup)

Both osmotic dehydration as well as applied power of microwaves during microwave drying in the reduced pressure conditions has a significant impact on the values of compression of dried pumpkin. It is confirmed by statistical analysis results, the part of which was presented in table 2. Dried material is characterized by an increased resistance in comparison to raw material. It is a particularly explicit relation for dried material obtained during drying with microwaves power of $480 \mathrm{~W}$. Statistical analysis did not prove significant differences between values of compression of dried material obtained from raw material dehydrated by means of osmosis in chokeberry and cherry sirup and between the results obtained for dried material from raw material which was not subjected to initial processing and dehydrated in apple sirup. Significance of osmotic dehydration on the resistance of apple tissues to compression is confirmed by research of Farris et al., (2008).

Figure 3 presents compression work values for the analysed dried material. In this case also results were referred to the raw material properties.

Drying pumpkin with the microwave method in the reduced pressure conditions leads to obtaining a product which is characterized by generally increased resistance to cutting in comparison to raw material. These are results concurring with the results of investigation of the cutting resistance of carrot dehydrated by osmosis before microwave and vacuum drying (Stępień, 2009). Statistical analysis proved that only dehydration by osmosis significantly changes the resistance of dried pumpkin to cutting. However, one should pay attention to the fact that values of cutting work for dried pumpkin not subjected to osmotic dehydration and dehydrated in chokeberry and cherry sirup decrease along with the in- 
Effect of osmotic dehydration...

crease of microwave power. In case of dried material obtained from dehydrated raw material in apple sirup the relation is reverse. Thus, statistical analysis did not prove the impact of microwaves power on the values of parameters. Among concentrates used for osmotic dehydration, apple sirup raises the product resistance to cutting in the highest degree. It results from the fact that dried material obtained from pumpkin dehydrated in the apple concentrate was the most fragile because during the cutting tests there were no cracks in the structure.

Table 2.

Results of statistical analysis of the impact of osmotic dehydration and microwaves power on mechanical and rheological properties presenting $p$ values of p-probability of hypothesis rejection 0)

\begin{tabular}{lcccc}
\hline & \multicolumn{4}{c}{ Mechanical and rheological properties } \\
\hline Factors & $P \dot{s}$ & $P p$ & $a$ & $b$ \\
\hline Osmotic dehydration & 0.023016 & 0.000000 & 0.000000 & 0.000000 \\
Microwaves power & 0.000001 & 0.374795 & 0.138448 & 0.379205 \\
\hline
\end{tabular}

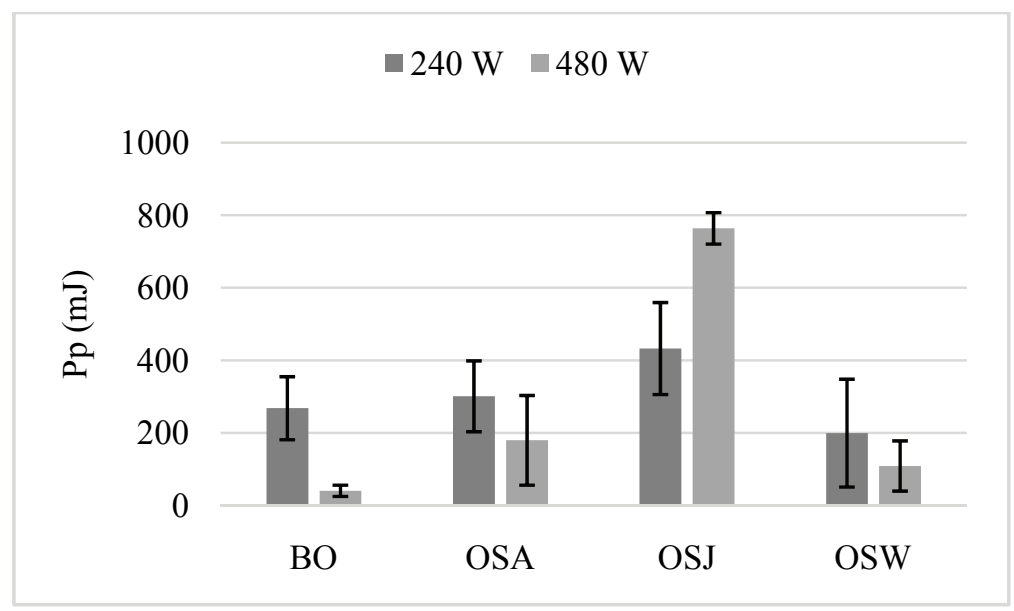

Figure 3. Values of cutting work of dried pumpkin ( $B O$ - without initial processing, OSA dehydrated in chokeberry sirup, OSJ - dehydrated in apple sirup, OSW - dehydrated in cherry sirup)

Analysis of elasticity of the obtained dried material was carried out based on the analysis of changes of values of stresses relaxation indexes $a$ and $b$. Their physical interpretation shows respectively the level and speed of stresses disappearance during the relexation test (Stropek and Gołacki, 2006; Stępień, 2009). If the value of indexes is closer to zero, the material has a greater elasticity (fig. 4). 


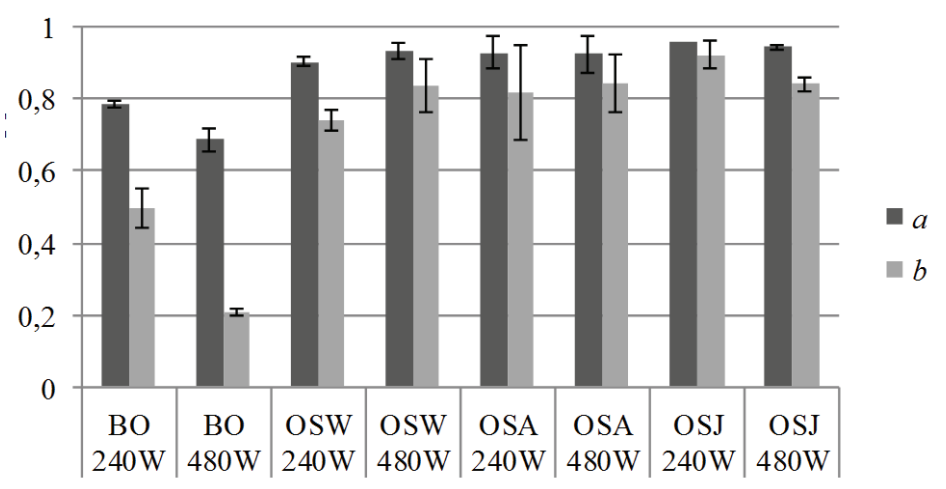

Figure 4. Values of stresses relaxation indexes of dried pumpkin (BO - without initial processing, OSA - dehydrated in chokeberry sirup, OSJ - dehydrated in apple sirup, OSW - dehydrated in cherry sirup)

Drying pumpkin with the microwave method in the reduced pressure conditions results in obtaining dried material with a lower elasticity than the dried material from raw material which was not subjected to initial processing. Statistical analysis confirms the significance of the osmotic dehydration impact on the values of both indexes (table 2). Generally the power of microwaves applied during drying has not significant impact on the elasticity of dried material. However, for dried material obtained from pumpkin not subjected to osmotic dehydration increase of microwaves power from 240 to $480 \mathrm{~W}$ causes approximately double decrease of the value of the index $b$ which proves high elasticity of dried material.

\section{Conclusions}

1. Osmotic dehydration of pumpkin before microwave drying in the reduced pressure conditions allows obtaining dried material which is more brittle, has an increased resistance to compression and cutting and has a lower elasticity in comparison to dried material obtained from raw material which was not subjected to initial processing.

2. The rise of microwave power during drying from 240 to $480 \mathrm{~W}$ causes a significant increase of the value of compression work for all investigated dried materials, while the decrease of the value of cutting work of dried pumpkin subjected previously to osmotic dehydration in chokeberry and cherry sirup.

3. The change of microwaves power has no significant impact on the elasticity of pumpkin which was dehydrated by osmosis before microwave drying in the reduced pressure conditions.

4. From among the investigated concentrates chokeberry and cherry sirup raise the compression resistance of pumpkin the most powerfully and the apple sirup raises the cutting resistance of dried material the most. 
Effect of osmotic dehydration...

\section{References}

Alibas, I. (2007). Energy consumption and colour characteristics of nettle leaves during microwave, vacuum and convective drying. Biosystems Engineering, 96(4), 495-502.

Ciurzyńska, A., Lenart, A. (2009). Wpływ zamrażania oraz odwadniania osmotycznego surowca w różnych roztworach na wybrane właściwości liofilizowanych truskawek. Acta Agrophysica, 14(3), 577-590.

Farris, S., Gobbi, S., Torreggiani, D., Piergiovanni L. (2008). Assessment of two different rapid compression tests for the evaluation of texture differences in osmo-air-dried apple rings. Journal of Food Engineering, 88, 484-491.

Garcia, C.C., Mauro, M.A., Kiura, M. (2007). Kinetics of osmotic dehydration and air-drying od pumpkins (Cucurbita moschata). Journal of Food Engineering, 82, 284-291.

Ghosh, P.K., Agrawal, Y.C., Jayas, D.S., Kumghar, B.K. (2004). Mass transfer kinetics model of osmotic dehydration of carrots. Transaction of the ASAE, 47(4), 1179-1185.

Jałoszyński, K., Szarycz, M., Surma, M., Steppień, B., Pasławska, M. (2010). Analiza suszenia mikrofalowo-próżniowego owoców róży dzikiej. Inżynieria Rolnicza, 1(119), 223-228.

Janowicz, M., Domian, E., Lenart, A., Pomarańska-Łazuka, W. (2008). Charakterystyka suszenia konwekcyjnego jabłek odwadnianych osmotycznie w roztworze sacharozy. Żywność. Nauka. Technologia. Jakość, 4(59), 190-198.

Khraisheh, M.A.M., Mcminn, W.A.M., Magee, T.R.A. (2004). Quality and structural changes in starchy foods during microwave and convective drying. Research Food International, 37, 497503.

Kowalska, H., Lenart, A. (2001). Mass exchange during osmotic pretreatment of vegetables. Journal of Food Engineering, 49, 137-140.

Lewicki, P.P., Vou, Le H., Pomarańska-Łazuka, W. (2002). Effect of pre-treatment on convective drying of tomatoes. Journal of Food Engineering, 54, 141-146.

Mui, W.W.Y., Durance, T.D., Scaman, Ch.H. (2002). Flavor and texture of banana chips dried by combinations of hot air, vacuum, and microwave processing. Journal of Agricultural and Food Chemistry, 50(7), 1883-1889.

Nawirska, A., Figiel, A., Kucharska, A.Z., Sokół-Łętowska, A., Biesiada, A. (2009). Drying kinetics and quality parameters of pumpkin slices dehydrated using different methods. Journal of Food Engineering, 94, 14-20.

Pereira, N.R., Marsaioli Jr., A., Ahrne, L.M. (2007). Effect of microwave power, air velocity and temperature on the final drying of osmotically dehydrated bananas. Journal of Food Engineering, $81,79-87$.

Pękosławska-Garstka, A., Lenart, A. (2010). Wybrane właściwości fizyczne miąższu dyni odwadnianej osmotycznie w roztworach cukrów. Acta Agrophysica, 16(2), 413-422.

Sham, P.W.Y., Scaman, Ch., Durance, T.D. (2001). Texture of vacuum microwave dehydrated apple chips as affected by calcium pretreatment, vacuum level, and apple variety. Journal of Food Science, 66(9), 1341-1347.

Sitkiewicz, I., Lenart, A. (2002). Influence of water activity on mechanical properties of osmotically pretreated dried fruit. Acta Agrophysica, 77, 137-146.

Sojak, M., Głowacki, Sz. (2010). Analysis of giant pumpkin (Cucurbita maxima) drying kinetics in various technologies of convective drying. Journal of Food Engineering, 99, 323-329.

Stępień, B. (2009). Modyfikacja cech mechanicznych i reologicznych wybranych warzyw pod wplywem różnych metod suszenia. Monografia LXXIX. Wydawnictwo Uniwersytetu Przyrodniczego we Wrocławiu, Wrocław.

Stępień, B., Jaźwiec, B., Pasławska, M., Jałoszyński, K., Surma, M. (2013). Wpływ suszenia fontannowo-mikrofalowego na jakość suszonej dyni. Inżynieria Rolnicza, 3(146), 371-380.

Stropek, Z., Gołacki, K. (2006). Metoda porównania przebiegów krzywych relaksacji naprężeń różnych materiałów roślinnych. Inżynieria Rolnicza, 12(87), 473-479. 


\section{WPLYW ODWADNIANIA OSMOTYCZNEGO NA WLAŚCIWOŚCI MECHANICZNO-REOLOGICZNE DYNI SUSZONEJ METODA MIKROFALOWĄ W WARUNKACH OBNIŻONEGO CIŚNIENIA}

Streszczenie. Celem badań było wykazanie wpływu rodzaju syropów użytych do odwadniania osmotycznego oraz mocy mikrofal suszenia mikrofalowo-próżniowego na wybrane cechy mechaniczne i reologiczne suszonej dyni. Dynię odmiany Rugosa odwodniono osmotycznie w trzech koncentratach: jabłkowym, aroniowym i wiśniowym. Wstępnie przygotowany materiał suszono metodą mikrofalową w warunkach obniżonego ciśnienia wahającego się w zakresie 6-4 kPa, przy mocach mikrofal wynoszących 240 i $480 \mathrm{~W}$. Susze poddano testom ściskania, przecinania oraz relaksacji naprężeń. Obliczono wartości pracy ściskania $(P s ́)$, pracy przecinania $(P p)$ oraz wskaźniki opisujące sprężystość materiału $(a$ i $b$ ). Zabieg wstępny w postaci odwadniania osmotycznego, wykonany przed suszeniem mikrofalowym w warunkach obniżonego, ciśnienia pozwala uzyskać suszoną dynię o podwyższonej odporności na ściskanie i na przecinanie oraz obniżonej sprężystości w stosunku do suszy uzyskanych z dyni nie poddanej zabiegowi wstępnemu. Moc mikrofal istotnie wpływa na wartości prac zarówno ściskania, jak i przecinania suszonej dyni.

Słowa kluczowe: dynia, suszenie, odwadnianie osmotyczne, cechy wytrzymałościowe 